\title{
Antimicrobial activity of the essential oil of Sida cordifolia $\mathbf{L}$.
}

\author{
Xirley Pereira Nunes ${ }^{1}$, Gabriela Lemos de Azevedo Maia ${ }^{1}$, Jackson Roberto Guedes da Silva \\ Almeida ${ }^{2}$, Fillipe de Oliveira Pereira ${ }^{3}$, Edeltrudes de Oliveira Lima ${ }^{3 *}$ \\ ${ }^{1}$ Universidade Federal da Paraiba, Laboratório de Tecnologia Farmacêutica, Caixa Postal 5009, 58051-970, \\ João Pessoa, Paraiba, Brasil, \\ ${ }^{2}$ Universidade Federal do Vale do São Francisco, Cx. Postal 252, 56306-410, Petrolina, \\ Pernambuco, Brasil, \\ ${ }^{3}$ Universidade Federal da Paraiba, Departamento de Ciências Farmacêuticas, \\ 58051-900, João Pessoa, Paraíba, Brasil
}

\begin{abstract}
RESUMO: “Atividade antimicrobiana do óleo essencial de Sida cordifolia L.”. A análise da atividade antimicrobiana do óleo essencial de Sida cordifolia foi avaliada com quatro diferentes cepas de bactérias e nove de fungos. O óleo essencial foi testado "in natura" $100 \%$ e diluído de 32 até $2 \%$. Os microrganismos, bactérias e fungos, foram semeados em ágar Muller-Hinton e Sabouraud dextrose, respectivamente. S. cordifolia mostrou atividade inibitória contra os microrganismos testados com eficácia de $80 \%$. Quando testado contra Staphyllococus aureus, Staphyllococus epidermidis, Candida guilliermondii e Trichosporon inkin o óleo essencial mostrou um melhor desempenho.
\end{abstract}

Unitermos: Sida cordifolia, Malvaceae, atividade antimicrobiana, óleo essencial.

\begin{abstract}
The analysis of the antimicrobial activity of the essential oil of Sida cordifolia was evaluated with four different strains of bacteria and nine fungi. The essential oil was tested "in natura" (100\%) and diluted from 32 until $2 \%$. The microorganisms, bacteria and fungi, were spread in agar Muller-Hinton and Sabouraud dextrose, respectively. S. cordifolia showed inhibitory activity against the microorganisms tested with efficacy of $80 \%$. When tested against Staphylococcus aureus, Staphyllococus epidermidis, Candida guilliermondii and Trichosporon inkin the essential oil showed the best performance.
\end{abstract}

Keywords: Sida cordifolia, Malvaceae, antimicrobial activity, essential oil.

\section{INTRODUCTION}

In the world of medicinal plants the aromatic plants constitute a prominent group mainly by the essential oils found in leaves, stems bark, resins, flowers, fruit bark and other parts.

The resistance of the bacteria to the innumerous antimicrobial agents constitutes one of the great challenges in the treatment of infections, conditioning to the necessity of searching and finding new sources of substances with antimicrobial proprieties to be used in the combat of microorganisms (Recio et al., 1989).

The Malvaceae family comprises about 120 genera and 1700 to 2000 species. The genus Sida is the third most diversified one of this complex family having 170 to 250 species around the world (Fuertes, 1993).

Sida cordifolia L. (Malvaceae) is a species with widespread distribution occurring in the tropical regions of the world mainly in America. In Brazil it is a common species found from north to south and is used as medicinal. In the Northeast region $S$. cordifolia is popularly known as "malva-branca" and is used in folk medicine for the treatment of rheumatisms, inflammations, asthma and in nasal congestions (Silveira et al., 2003).

The aqueous extract of the leaves of $S$. cordifolia showed anti-inflammatory activity (Falcão et al., 2005) and the acetone extract of the roots inhibited the angiotensin converting enzymes (Barbosa-Filho et al., 2006). Phytochemical studies with this plant leaves have revealed the presence of quinolizidine alkaloids, such as vasicine, vasicinone and vasicinol (Ghosal et al., 1975). Pharmacological studies conducted in our laboratory identified the cardiovascular activity of the alkaloid vasicine by Silveira et al. (2003). In this work the antimicrobial activity of the essential oil of $S$. cordifolia against some bacteria and pathogenic fungi is reported.

\section{MATERIAL AND METHODS}

\section{Botanical material}

The plant was collected in December 2004, near the city of Santa Rita, State of Paraíba, Brazil, a coastal area around the Atlantic Forest. The voucher samples 
Table 1. Halos diameter average $(\mathrm{mm})$ of the evaluation of the MIC of the essential oil of Sida cordifolia against bacteria and fungi, in solid medium.

\begin{tabular}{|c|c|c|c|c|c|c|c|c|c|}
\hline \multirow[b]{2}{*}{ Microorganisms } & \multicolumn{6}{|c|}{ Essential oil (\%) } & \multicolumn{3}{|c|}{ Control } \\
\hline & 100 & 32 & 16 & 8 & 4 & 2 & 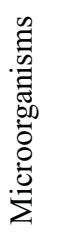 & 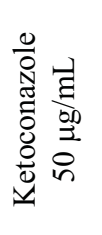 & 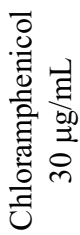 \\
\hline S. aureus ATCC 25923 & 17 & 13 & 12 & 8 & 0 & 0 & + & - & 22 \\
\hline S. epidermidis ATCC 12228 & 16 & 12 & 10 & 7 & 0 & 0 & + & - & 16 \\
\hline M. luteus ATCC 9341 & 12 & 10 & 7 & 0 & 0 & 0 & + & - & 20 \\
\hline P. aeruginosa ATCC 27853 & 0 & 0 & 0 & 0 & 0 & 0 & + & - & 10 \\
\hline C. albicans ATCC 90028 & 14 & 13 & 12 & 0 & 0 & 0 & + & 10 & - \\
\hline C. guilliermondii LM 28 & 20 & 15 & 12 & 10 & 7 & 0 & + & 12 & - \\
\hline C. krusei LM 07 & 12 & 10 & 8 & 0 & 0 & 0 & + & 0 & - \\
\hline C. stellatoidea LM 96 & 0 & 0 & 0 & 0 & 0 & 0 & + & 14 & - \\
\hline C. tropicalis LM 25 & 14 & 10 & 7 & 0 & 0 & 0 & + & 12 & - \\
\hline T. inkin LM 267 & 24 & 22 & 16 & 12 & 8 & 0 & + & 0 & - \\
\hline T. rubrum LM 105 & 0 & 0 & 0 & 0 & 0 & 0 & + & 10 & - \\
\hline T. mentagrophytes LM 103 & 12 & 10 & 0 & 0 & 0 & 0 & + & 12 & - \\
\hline Penicillium FCF 281 & 0 & 0 & 0 & 0 & 0 & 0 & + & 0 & - \\
\hline
\end{tabular}

(Agra et Góis 6243) were deposited in the Herbarium Prof. Lauro Pires Xavier (JPB) and in the reference collection of the Laboratório de Tecnologia Farmacêutica of the Universidade Federal da Paraíba, Brazil.

\section{Extraction of the essential oil}

Fresh leaves of $S$. cordifolia $(1000 \mathrm{~g})$ were cut into pieces, and subjected to steam distillation in a Clevenger-type apparatus (Matos et al., 1999). The essential oil obtained $(0.06 \% \mathrm{w} / \mathrm{w})$ had yellow color and characteristic odor and was dried over anhydrous sodium sulfate and filtered. The oil was kept in amber bottle flask and maintained in temperature lower then $4^{\circ} \mathrm{C}$.

\section{Microorganisms}

For the bioassays 4 bacteria and 9 fungi were used: Staphylococcus aureus (ATCC 25923), Staphylococcus epidermidis (ATCC 12228), Micrococcus luteus (ATCC 9341), Pseudomonas aeruginosa (ATCC 27853), Candida albicans (ATCC 90028), Candida guilliermondii (LM 28), Candida krusei (LM 07), Candida stellatoidea (LM 96), Candida tropicalis (LM 25), Trichosporon inkin (LM 267), Trichophyton rubrum (LM 105), Trichophyton mentagrophytes (LM 103) and Penicilium (FCF 281).

\section{Culture media}

The assays for the antimicrobial activities were carried out in agar Muller-Hinton (Merck) and agar Sabouraud dextrose-ASD (Difco) for bacteria and fungi, respectively.

\section{Assays of antimicrobial activities}

The essential oil was tested "in natura" (100\%) and in dilutions from 32 until $2 \%$, according to Allegrini et al. (1973). For this purpose, $1.2 \mathrm{~mL}$ of the oil, $0.04 \mathrm{~mL}$ of Tween 80 (Sigma Chemical) and sterile distilled water enough to complete $5 \mathrm{~mL}$ were placed in sterile glass tubes, $70 \times 10 \mathrm{~mm}$ ( $32 \%$ dilution). The resultant emulsion was homogenized in agitator Vortex (FANEM) for five minutes. The seriate dilutions were made in proportion of two. Beginning at the first tube, $2.5 \mathrm{~mL}$ were transferred to a second one, which contained $2.5 \mathrm{~mL}$ of sterile distilled water following by agitation and homogenization. This process was successively repeated until the sixth dilution, corresponding to $2 \%$. The tests performed to evaluate the antibacterial and antifungal activity of the volatile oil were carried out by the method of diffusion in solid media (Bawer et al., 1996; Cleeland; Squires, 1991). 1 $\mathrm{mL}$ of suspension of each microorganism, previously prepared, was deposited in dischargeable and sterile Petri dishes $(15 \times 90 \mathrm{~mm})$, to which were previously added $20 \mathrm{~mL}$ of ASD with slow homogenization. Cavities were made with sterile glass cannulas with $6 \mathrm{~mm}$ in diameter in the solid culture media and were inoculated with $50 \mu \mathrm{L}$ of each dilution of the tested oil. The controls were made for each microorganism with the standard antimicrobial chloramphenicol at $30 \mu \mathrm{g} / \mathrm{mL}$ for bacteria, and ketoconazole at $50 \mu \mathrm{g} / \mathrm{mL}$ for fungi. The assay system was incubated at $37^{\circ} \mathrm{C}$, during $24-48$ hours for bacteria and leveduriform fungi; and at room temperature 
in a period of $10-14$ days for the filamentous fungi. Each assay was carried out in duplicate and the results were expressed by arithmetic media of the halos of inhibition obtained. The biological activity of the oil was considered positive when the media of the inhibition of the halos were equal or superior to $10 \mathrm{~mm}$ in diameter.

\section{RESULTS AND DISCUSSION}

The antimicrobial activity results of the oil against the bacteria and fungi can be seen in Table 1 .

The essential oil of $S$. cordifolia was able to inhibit the growth of three of the four strains of bacteria tested. However, it was more effective against Staphylococcus aureus e S. epidermidis, up to the dilution of $8 \%$ with inhibition halos of an average of $12 \mathrm{~mm}$ in diameter.

Among the fungi strains tested, seven were sensitive to the oil of S. cordifolia, representing $70 \%$ of the tested strains. Concerning the leveduriform fungi, C. guilliermondii and Trichosporon inkin were the most sensitive ones to the oil up to the dilution of $8 \%$, with inhibition halos of an average of $13 \mathrm{~mm}$ in diameter. Being only $C$. stellatoidea resistent to the essential oil. Regarding Candida albicans, C. krusei, C. tropicalis, they were sensitive to the oil at the concentration of $16 \%$, with inhibition halos of an average of $10 \mathrm{~mm}$ in diameter.

Among the filamentous fungi tested, the oil at the concentration of $32 \%$, inhibited the growth of only T. mentagrophytes, with inhibition halos of an average of $10 \mathrm{~mm}$ in diameter.

This study led to the conclusion that the antimicrobial activity of the essential oil of Sida cordifolia was satisfactory against the bacteria and fungi tested. These results are important as a preparation for further research with this same material. However, this essential oil needs to have adequate toxicological studies carried out in order to verify the possibility of its use in the fight against the microorganisms tested.

\section{ACKHNOWLEDGEMENTS}

The authors are grateful to CAPES and CNPq (Brazil) for grants and fellowships and express their thanks to the College of Pharmacy of the University of Illinois, Chicago, USA, for granting access to the NAPRALERT database.

\section{REFERENCES}

Allegrini J, Bouchberg MS, Maillols H 1973. Emulsions d'huiles esentielles fabrication et applications en microbiologie. Societé de Pharmacie de Montpellier 33: 73-86.

Barbosa-Filho JM, Martins VKM, Rabelo LA, Moura MD, Silva MS, Cunha EVL, Souza MFV, Almeida RN, Medeiros IA 2006. Natural products inhibitors of the angiotensin converting enzyme (ACE). A review between 1980-2000. Rev Bras Farmacogn 16: 421446.

Bawer AW, Kirby WM, Sherris SC, Turck M 1996. Antibiotic susceptibility testing by a standardezid single disc method. Am J Clin Pathol 45: 493-496.

Cleeland R, Squires E 1991. Evaluation of new antimicrobials "in vitro" and in experimental animal infections. Antibiotics in Laboratory Medicine 3: 739-787.

Falcão HS, Lima IO, Santos VL, Dantas HF, Diniz MFFM, Barbosa-Filho JM, Batista LM 2005. Review of the plants with anti-inflammatory activity studied in Brazil. Rev Bras Farmacogn 15: 381-391.

Fuertes FJ 1993. Revisión taxonômica del gênero Sida L. (Malvaceae) em Colômbia. Salamanca: Universidad de Salamanca/Facultad de Biologia. Departamento de Biologia Vegetal.

Ghosal S, Chauhan RBPS, Mehta, R 1975. Chemical constituents of Malvaceae. Part I. Alkaloids of Sida cordifolia. Phytochemistry 14: 830-832.

Matos FJA, Machado MIL, Craveiro AA, Barbosa-Filho JM 1999. Essential oil of Mentha $x$ vilosa Huds. $J$ Essent Oil Res 11: 41-44.

Recio MC, Rios JL, Villar AA 1989. Review of some antimicrobial compounds isolated from medicinal plants reported in the literature 1978-1988. Phytother Res 3: 117-125.

Silveira AL, Gomes MAS, Santos MRV, Medeiros IA, BarbosaFilho JM 2003. Evaluation of the cardiovascular effects of vasicine, an alkaloid isolated from the leaves of Sida cordifolia L. (Malvaceae). Rev Bras Farmacogn 13: 37-39. 